\title{
Images of Interracialism in Contemporary American Crime Fiction
}

\section{Tarik Abdel-Monem}

Racial clues have always been written into crime fiction. Sherlock Holmes was as much an anthropologist as he was a detective. The venerable investigator of Britain's imperial empire could as easily differentiate between the footprints of a Hindu or Muslim as he could identify the Chinese origins of a tattoo by its color. $^{1}$ Although these types of racialized — and often racist—depictions are no longer mainstays of the genre, race still plays a central role in many contemporary works of crime fiction. Modern writers have brought new perspectives on race, justice, and social inequalities to contemporary crime stories, infusing the crime narrative with critical race, feminist, post-colonial, gay/lesbian, and other perspectives. Today's authors are just as likely to find evil in individual villains as they are in racism, sexism, corporate greed, or political institutions. Crime fiction has thus become more and more a platform for social commentary as well as entertainment. But if race still has meaning and relevance to the detective story, it begs the question of what the significance is of interracialism in the criminal worlds of our collective imaginations.

As America continues its Quixotic quest for a post-racial new world, an examination of our interracial imaginings poses important questions. In popular thought, miscegenation serves as an ideological symbol representing everything from racial genocide to racial harmony, from social destruction to social progress (Olumide 2002, 1-2). This article provides an overview of how ideologies of interracialism inhabit contemporary works of crime fiction. My argument is that 
certain themes prevalent in earlier American literature have transferred quite comfortably into the modern crime genre, attesting to the longevity and persistence with which particular tropes of interracialism resound within the popular culture generally. Over 150 years after the flourishing of the tragic mulatto archetype, this recurring trope has found a welcome home in many of today's crime novels. If one reads the crime story as a narrative about social morality, then the persistence of abject depictions of interracialism seem to affirm a continuing reluctance to perceive race-mixing favorably.

Yet we also see in modern crime novels continual reference to a competing stereotype, that of the exceptional, multiracial super-being. Here, authors employ interracialism as a remedy or apology to the legacy of racism and racial division. The multiracial person is depicted as an exceptional being with physical and mental traits superior to monoracial persons. This trope also derives some of its content from the tragic mulatto tradition, but is informed more by a willingness to depict miscegenation as a socially beneficial development. In the structured and conservative crime fiction milieu, miscegenation can thus be employed to de-center traditional conventions and make bold — or naive - statements about modern American society and the role of race or interracialism in the development of a future ethos.

The scope and depth of contemporary American crime fiction is vast and diverse. Like all forms of popular fiction, the crime story and its many sub-genres continue the process of evolution and reinvention. My exploration is a modest attempt at outlining basic contours of the more apparent - and, as I argue, the more troubling - trends relevant to depictions of interracialism in the genre. This article proceeds first by briefly outlining the tragic mulatto trope in earlier American literature, but will then concentrate on providing an overview of several contemporary works of crime fiction. All contemporary novels examined were chosen as examples of works which both feature prominent depictions of interracialism, and exist within modern times. Novels either written during or set in pre-Loving v. Virginia (1967) America are not examined in this article because they depict an earlier ethos about race and interracialism which departs from our contemporary zeitgeist. Four works will be examined specifically. Michael Crichton's Rising Sun (1992), Lea Waits' Shadows of the Spring Show (2005), and Richard Lupoff's The Silver Chariot Killer (1996) are all works which prominently feature either or both of the interracial tropes noted above, and more importantly, deploy them to further their respective stories. I also examine Gary Hardwick's Color of Justice (2002) as an example of a work that makes reference to the same themes as the former novels, but does not readily accept such fictives. A brief summary of other contemporary crime novels will also be outlined to show the extent to which these tropes have gained wider use within the genre. 


\section{Early Depictions of Miscegenation in American Literature}

Both overt and concealed references to miscegenation have existed in storytelling traditions. From Heliodorus' Aethiopica to One Thousand and One Nights, tales of interracialism exist as a lineage of origin stories, moral parables, and comedies. Although the story of The Moor and Desdemona may be the most visible tragedy of interracial romance in the early modern English tradition, miscegenation's most enduring trope in American literature was born from slavery and its aftermath. White abolitionist writers like Lydia Maria Child constructed the archetype of the tragic mulatto to agitate against slavery. The irony of dehumanizing the mixed-race person for purposes of humanization is certainly not lost. Infusing misfortune and calamity into depictions of mulattoes was done to create sympathy for half-white, half-black slaves (Bost 2003, 60-68; Bullock 1945, 78). ${ }^{2}$ In such depictions, the lives of these characters were coded with recurring catastrophes and woes; violence, mental and spiritual anguish, illness, death, and powerlessness.

In both Child's The Quadroons (1842) and Slavery's Pleasant Homes (1843), the central characters are mulattoes who are ultimately killed in fruitless quests for justice, love, or freedom from bondage. In The Quadroons, the story's main character is a beautiful young girl descended from a light-skinned black woman and white man:

Her flexile form and nimble motions were in harmony with the breezy sound of the name; and its Moorish origin was most appropriate to one so emphatically "a child of the sun." Her complexion, of a still lighter brown than Rosalie's, was rich and glowing as an autumnal leaf. The iris of her large, dark eye had the melting, mezzotinto outline, which remains the last vestige of African ancestry, and gives that plaintive expression, so often observed, and so appropriate to that docile and injured race. (Child 1842, 118-119)

Her fate, however, is to be sold into slavery on an auction block, while still a teenager: "There she stood, trembling, blushing, and weeping; compelled to listen to the grossest language, and shrinking from the rude hands that examined the graceful proportions of her beautiful frame." (Child 1842, 138)

Such imagery was used to appeal to white reader sensibilities by assaulting conventions concerning the chastity and integrity of women. In the early depictions of mulattas, their exoticism and physical beauty typically resulted in abnormal sexual access. Rape and sexual vulnerability became a stock theme in abolitionist writings, epitomizing the powerlessness and injustice experienced by the mixed-race female slave (Zanger 1966, 64). Longfellow's poem "The Quadroon" is an emblematic example of this image - the enslaved mulatta displayed as an erotic female body before being sold away: 
Before them, with her face upraised,

In timid attitude,

Like one half-curious, half-amazed,

A Quadroon maiden stood.

Her eyes were large, and full of light,

Her arms and neck were bare;

No garment she wore save a kirtle bright,

And her own long raven hair.

And on her lips there played a smile

As holy, meek, and faint,

As lights in some cathedral aisle

The features of a saint.

The Slaver led her from the door,

He led her by the hand,

To be his slave and paramour

In a strange and distant land!

The tragedies presented and popularized by the abolitionists were clearly controversial. Child's anti-slavery writings were deemed too radical by many in her time (Kenschaft 2002, 41-60), and the banning of abolitionist works from Hildreth's The Slave (1836) to Uncle Tom's Cabin (1852) was quite common, particularly in the south and mid-Atlantic states. Little space was allowed for any portrayal of mixed-race persons or interracialism beyond the tragic mulatto figure. In its $19^{\text {th }}$ century American context, the foundational published literature about miscegenation was therefore primarily a body of work - written exclusively by white authors - bound within tight parameters with little space for deviance (Sollors 1997, 26-29). Out of this vacuum, the tragic mulatto trope embedded itself in the social and literary space allowed to it.

This is not to say that the post-abolitionist literature of interracialism was a unified body of work, nor that succeeding authors limited themselves to the formulas of the original texts. One of the more visible stories featuring interracialism, Faulkner's Absalom, Absalom!, made use of the tragic mixed race figure in its explorations of miscegenation in 1830's antebellum America, but for much different ends than the stock treatment afforded by the original abolitionists. Charles Bon was clearly Faulker's vehicle to both condemn and usurp southern mores (Kartiganer 1965, 303; Kohler 1949, 124-125; Zender 1998, 752). ${ }^{3} \mathrm{He}$ embodied the atrocity of slavery, but unlike the silenced mixed-race victims of the abolitionist works, Faulkner reversed the direction of causality by making Charles Bon a passing avenger - "the nigger that's going to sleep with your sister" (Faulkner 1936, 358). Also significant is Twain's Pudd'nhead Wilson, another text that was, for Twain's age, quite unconventional. It too relied on 
vigorous recreations of the tragic mulatto (Jehlen 1990, 42-45; Marcus, 1990, 199). Roxy is an exotic and beguiling figure. "Her face was shapely, intelligent, and comely - even beautiful" and she possesses the wiles and cunning to deceive her master, but her life is tortured and pitiable - a prototypical representation of the tragic mulatta character (Brown 1933, 192-196; Rowlette 1971, 5-13). ${ }^{4}$ But importantly, as social commentary, Puddn'head accomplished its major objectives of both denouncing the cruelty of slavery and racism, and presented race as a social construction.

\section{Interracialism in Contemporary Crime Fiction}

Puddn'head did, of course, remove any interracial space in favor of collapsed polarities of white and black. Twain's treatment of interracialism-or lack thereof - was dictated not only by the parameters of the story's setting in antebellum Missouri, but also by the prevailing conventions of the "one-drop" rule embedded in law. The persistent stubbornness by which this black/white dichotomy still exists is a testament to its enduring significance and the pervasiveness of texts that reproduce the racial system in postmodern society. But the social context continues to change. Among non-white communities, the social movements of the 1960s and 70s brought a new willingness to define or redefine communal boundaries along racial lines. The Black Pride, Asian-American, American Indian, and Latino Movements activated an awareness of race which aligned communities around singular polarities for racial solidarity. Interracial marriage meant compromising one's community. Passing meant selling out. Yet demographically, the racial middle ground that Twain had denied has clearly exploded. In post-Loving $v$. Virginia America, increasing rates of interracial marriage have expanded a racial continuum that defies monoracial definitions. The demographic trends are undeniable. Loving thus threw the ball into the people's court to contest the meaning and value of interracialism.

Contemporary crime fiction has somewhat hesitantly embraced the challenge, albeit with mixed results. Unquestionably, today's crime stories have turned the genre as a whole on its head, at least ideologically. One would be hard pressed to find a modern work that embraces the Victorian racism of Holmes or the racist and sexist overtones of the hard-boiled genre. Although story forms might be the same, protagonists in today's American crime story might have been the villains of yesterday's crime novels (Cawelti, 1997, 6-8, Libretti, 1999, 61-62). Contemporary crime fiction has gradually incorporated heroes and heroines of color, women, and sexual minorities into its pages. African-American novelists like Walter Mosely, Barbara Neely, Pamela Thomas-Graham, and a host of others have achieved popular and critical success by using the detective story as a platform mixing entertainment with social commentary. The Navajo detectives Jim Chee and Joe Leaphorn have reached enormous popularity in the works of Tony Hillerman. Yet despite the certainty with which contemporary American crime fiction has extended its reach to embrace non-white, monoracial protago- 
nists or settings, the landscape with which interracialism is the focus is still both limited, and contested. Both old and new tropes inhabit this growing space.

Michael Crichton's Rising Sun (1992) - a procedural which employs U.S.Japanese industrial espionage as its backdrop - is perhaps the most well-known of the works I examine here. Crichton wrote a number of science fiction thrillers and mysteries that became best-selling novels, including The Andromeda Strain (1969), The Terminal Man (1972), The Great Train Robbery (1975), Eaters of the Dead (1976), Congo (1980), Sphere (1987) Jurassic Park (1990), and Disclosure (1994), many of which were made into successful films. Rising Sun was published at a time when economic tensions between the United States and Japan were high. Despite a strong post-World War II alliance, the U.S. ran a consistent trade deficit with Japan in the 1980s, a trend which reflected Japan's successful export-oriented economy and the postmodern decline in American manufacturing. Japan had also become a major creditor nation to the United States and a highly visible direct investor, a development which generated a degree of rivalry and even resentment among many Americans. After the release of Rising Sun, a New York Times reviewer noted that it "makes one wonder if contending with Japan isn't going to be the United States' next great mission now that the cold war is over." (Lehmann-Haupt, 1992)

Rising Sun opens with the discovery of the dead body of a young, white, American woman found in a Los Angeles-based Japanese corporate building. The story's narrator and the LAPD investigator given the case, Smith, is a young diplomatic liaison who is assigned to work with Connor, an eccentric older investigator who had previously lived in Japan and is a de facto "expert" on Japanese culture. Connor and Smith have a classic Holmes-Watson relationship as the older and wiser mentor paired with a naïve partner. The formula works well for Crichton's narrative and the structure of the story. Connor is presented to the reader through Smith's narration as the more experienced and capable investigator who is the true engine of the story's detective work, largely as a result of his familiarity with Japanese culture and language.

The two investigators inhabit a Holmesian universe in the sense that Connor's skills as a detective are-like Holmes - derived from his abilities as an expert of the racialized other. Crichton deploys Connor throughout the story as the expert observer and interpreter of the Japanese, who are presented as alien and hostile bodies in rather standard orientalist protocol. Shortly after confronting one of the Japanese businessmen employed by the suspect corporation where the dead woman was found, Connor is able to proffer textbook-like analysis of Japanese behavior to his junior partner:

"It's just that Americans believe there is some core of individuality that doesn't change from one moment to the next. And the Japanese believe context rules everything."

"It sounds to me," I said, "like an excuse for lying."

"He doesn't see it as lying." 
"But that's what it is."

Connor shrugged. "Only from your point of view, kōhai. Not from his."

"The hell."

"Look, it's your choice. You can understand the Japanese and deal with them as they are, or you can get pissed off. But our problem in this country is that we don't deal with the Japanese the way they really are." (54)

As an American with a command of the Japanese, Connor utilizes his understanding of their behavior to identify anthropological clues and deduce significance from them. Connor's ability to infer meaning from Japanese bodies plays an important role in his investigation:

"It's because of the time sequence. You see, the murder was reported at eight thirty-two. Less than fifteen minutes later, at eight forty-five, a Japanese man was down there switching the tapes, arranging a cover-up. That's a very fast response. Much too fast for a Japanese company."

"Why is that?"

"Japanese organizations are actually very slow to respond in a crisis. Their decision-making relies on precedents, and when a situation is unprecedented, people are uncertain how to behave. . . . A Japanese organization simply cannot move fast in a new situation."

"But an individual acting alone can?"

"Yes. Exactly."

I said, "And that's why you think the man with the briefcase may be the killer."

Connor nodded. "Yes. Either the killer, or someone closely connected with the killer." (55)

Throughout Rising Sun, references are made to highlight U.S.-Japanese tensions. The reliance on yellow peril imagery is rife: "The government. They own the government. You know what they spend in Washington every year? . . . Shit. The end of America, buddy" (242). The premise of the crime - a white, American woman raped and then murdered by Japanese men - provokes a racial and nationalist antipathy that underlies the story. This is also reinforced by a spatial narrative. The body of the dead prostitute is found in the boardroom of a Japanese corporation in downtown Los Angeles, an obvious symbol of Japanese penetration in America as a result of its economic successes. The fact that the crime occurs within the confines of a corporate boardroom owned by the Japanese smacks of a sinister level of impunity because the murder happened within a foreign sphere both inside but separate from America. Crichton cavalierly 
employs imagery of secretive, alien spaces peopled with Japanese bodies that exist in America:

\begin{abstract}
"You must understand," Connor said, "there is a shadow world - here in Los Angeles, in Honolulu, in New York. Most of the time you're never aware of it. We live in our regular American world, walking on our American streets, and we never notice that right alongside our world is a second world. Very discreet, very private. Perhaps in New York you will see Japanese businessmen walking through an unmarked door, and catch a glimpse of a club behind. Perhaps you will hear of a small sushi bar in Los Angeles that charges twelve hundred dollars a person, Tokyo prices. But they are not listed in the guidebooks. They are not a part of our American world. They are part of the shadow world, available only to the Japanese."
\end{abstract} (57)

The interracial, sexual element of the crime drives the story's tensions. It is revealed that the dead American woman worked in a highly-paid prostitution ring with an exclusive Japanese clientele. Evoking stereotypes of oriental sexual cruelty, the Japanese clients are as rich as their tastes are perverse with white American women. As one of the other American prostitutes says: "They think nothing of dropping ten or twenty thousand in a night. It's like a tip for them. . .. A lot of them, they are so polite, so correct, but then they get turned on, they have this ... this way ..." (64). The victim herself, it is revealed, enjoyed bondage and sexual asphyxiation with her Japanese partners, the likely cause of her murder. The interracial sexual act in Rising Sun is thus imbued with inferences of sadism and death originating from desires of the alien Japanese.

Into this racialized environment, enters Theresa Asakuma, a young, halfJapanese, half-black American woman who aids Smith and Connor in their investigation. Theresa is a highly gifted graduate student who works at a university research center. Her talents and understanding of video technology ultimately play a critical role in solving the case of the murdered prostitute. She is also physically striking. Upon first meeting the detectives, Theresa is presented as a beautiful, exotic, and sexual young woman:

She was dark, exotic-looking, almost Eurasian. In fact she was beautiful, drop-dead beautiful. She looked like one of those high cheek-boned models in magazines. And for a moment, I was confused, because this woman was too beautiful to be working in some basement electronics laboratory. (Crichton 1992, 181) 
However, Smith later discovers that she is also significantly deformed: "Then I saw that her right arm was withered, ending in a fleshy stump protruding beyond the sleeve of her jeans jacket. It looked like the arm of a Thalidomide baby" (182). Her body is thus cursed with a uniquely beautiful face, but a grossly malformed arm - a blatant indication of at best, abnormality, at worst, outright aberration. Given the extent to which racialized, national rivalry underpins the story's plot, Crichton's reduction of Theresa into a disfigured body makes sense. In such a universe, off-spring of a Japanese/Black-American union could only be both uniquely beautiful and talented, but also defective.

In time, Smith also learns that Theresa has a deeply personal grudge. She grew up in Japan, and was treated as an outcast because of both her deformity and her mixed-race heritage. She was a burukumin - "[T]he untouchables of Japan. The outcasts. The lowest of the low. ... And I was lower than burukumin, because I was deformed" (261). Revenge is her motivation to help the detectives solve a crime committed by Japanese businessmen: "You cannot imagine the harshness of life in Japan, if you are excluded from the group. But I know it very well. And I do not mind if the Japanese suffer a little now, from my efforts" (261). Thus, the social rejection she experienced as a child drives her resentment of the Japanese. The duality with which Crichton uncritically trivializes Theresa Asakuma is clearly stereotypical in its employment of the tragic mulatta. She is beautiful and uniquely talented, yet has a grossly deformed arm and a deeply troubled soul, the product of a relationship that should not have existed.

Lea Wait's Shadows At The Spring Show (2005) also highlight the tragic connotations of multiracialism. It was Wait's fourth work featuring Maggie Summers, a college professor and antique print dealer who is the story's protagonist. Shadows concerns a murder among a community of multiracial and transracially adopted children and their parents in a New England college town. Summers has volunteered to manage a fundraising event for a local adoption center. Through her volunteer work, she becomes acquainted with Carole Drummond, the adoption center's director. Carole is an Asian adoptee, who has taken into her home Hal, a troubled young man.

The town's troubles begin shortly after Carole informs Maggie that the center has begun receiving mysterious threats warning them to not hold the fundraising benefit. Summers is a single, white widower who has herself considered adopting children. But she soon learns from Carole that resistance to transracial adoption might be the motivation behind the threats:

"Some people are still opposed to agencies placing children with parents of different races or religions or cultures. . . . Some people believe that only parents of the same heritage as a child can give that child a sense of history and community. That, for instance, we're destroying the heritage of a Korean child when we place him or her with a Caucasian family."

Maggie had remembered the pictures in Carole's office. 
Carole's parents — her adoptive parents — were white. She had been born in Seoul, Korea.

"How serious is the letter?"

"It's clearly a threat." Carole hesitated. "Not the first contact from this person, either." (Wait 2005, 11-12)

The potential suspects are all disturbed adolescents or young adults who are affiliated with the center through transracial adoption or foster care. Intimations to the dysfunction of transracial adoption are reflected in the portrayals of these teens, almost all of whom have traumatized backgrounds. One of the young men lost a brother in the September $11^{\text {th }}$ World Trade Center attacks. Another was abused as a child, and later lost both parents in a house fire.

Tension builds after a white adoptive mother-Holly Sloane - is shot and seriously wounded by an unknown attacker. Shortly thereafter, Holly's adopted son Jackson mysteriously disappears, and he becomes the main suspect. Jackson is a deeply troubled young man. He is resentful at both his adoption, as well as for being biracial: “[H]e still hasn't totally bonded with the family, or accepted who he is. . . his mother was white and his father was black. He's still not comfortable with that, or now, with having white adoptive parents" (8-9). The police thus suspect that Jackson may have shot his white mother out of anger for adopting him. And despite being half-white and half-black, he would have preferred his parents to be black. As explained by his brother, another transracial adoptee:

"They try really hard. They've read all the books and they know what happens. But they're not black, so they don't feel race the same way Jacks and I and the other kids do. Sometimes Jackson's really angry about being in this family. He thinks it would have been easier for him if Mom and Dad had been black." (90-91)

As Shadows progresses, Summers becomes further exposed to dysfunction either created by or resulting from interracialism. As a prospective adoptive mother, a transformation occurs as the plot develops. Upon first being introduced, Summers has a rosy and idealized perception of transracial adoption. She views Carole as an almost flawless product of transracial adoption:

Carole Drummond, a Korean-American in her late thirties, was tall, slim, and an advertisement for the joys of adoption. She'd arrived home to her adoptive parents when she was just four months old. By the time she was six months old she'd probably had those parents organized and scheduled and changing her own diapers. . . . Carole was Maggie's new role model. 
Volunteering to run the antiques show had given her a chance to watch Carole in action. (3)

Yet her continuing encounters with the troubled, racially-mixed adoptees leads her to change her mind. She finds that another white, prospective adoptive mother-Ann—has similar concerns:

I thought I might be able to adopt a child of another race. I know lots of people do, and some of the kids are really cute. But the more I think about the future, and about what it would mean to bring up a child of another race or color, the more I'm not sure it's something I'm ready for. (Wait 2005, 14)

Eventually, Summers concludes that transracial adoption might be too problematic for her. The tensions between Holly and her adopted son highlight her apprehensions: "Ann was correct in thinking that adopting an older child, one who came with emotional baggage and might be from another race, or from another culture, would change her life completely. Was she ready to cope with all the issues Holly and Rob dealt with every day?" (53). In this sense, Shadows reflects some of the concerns that allegedly exist in regards to transracial adoption. ${ }^{5}$ Through her focus on the dysfunctional behaviors and backgrounds of almost all the adopted adolescents, and the negative effects on multi-racial families, Waits emphasizes and frames transracialism as a destructive and disturbing phenomena. The conventionality of the ordinary family is juxtaposed with the turbulence caused by multiracialism within the family.

The pattern of tragedy within Shadows continues to engulf the rest of the story's characters. Threats to the adoption agency escalate, and the missing son Jackson is later found killed. At the story's conclusion, a bomb is set to detonate at the adoption center's fundraising event, and Summers finally discovers and confronts the villain: Hal, another adoptee who lives with Carole's multiracial family. As alluded to earlier in Shadows, Hal's crimes are motivated by his own sense of isolation and rage at being adopted. Not only had he targeted the adoption agency and adoptive mother Holly, but he killed Jackson out of a perceived mission of mercy:

You mess with ethnic purity. You condemn the future of America by creating families of mixed races. Those families can't protect their kids from hatred. Those kids won't fit in. ... I'm sorry about Jackson. I thought I was doing him a favor. After we met at one of those rah-rah-adoption picnics at your house, he told me what it felt like to be biracial. He hated it. He said he hated his mother; she was white, like his birth mother, and she thought she could take the place of a real mother. (234-235) 
Jackson's tragedy was thus both his life lived - as a biracial and transracially adopted child - and his life ended, also by a similarly troubled adoptee. Although Hal is clearly deranged, Shadows' highlighting of interracial adoption as the cause for such pain and mayhem signifies its aberrant nature.

The references to the tragic mulatto figure in Shadows and Rising Sun juxtapose with the depiction of interracialism in Richard Lupoff's The Silver Chariot Killer (1996). Silver Chariot is the sixth novel in Lupoff's Hobart Lyndsey and Marvia Plum novels. Lyndsey is a white male investigator for an insurance company, and Plum is a black female police detective. In addition to working together to solve crimes, Lindsey and Plum also have a recurring romantic relationship. The Lyndsey/Plum novels are thus a rare detective series in which the featured protagonists are interracially involved. Their relationship over the length of the series is, however, on-again/off-again, thus providing the novels with a side plot of romantic and sexual tension. Interracialism features prominently throughout Silver Chariot. Lyndsey is assigned to investigate the death of a former black colleague, Cletus Berry, who was found murdered in a New York City alley. Both Lyndsey and Cletus had previously worked together in an insurance investigation, and because of that personal history, Lyndsey becomes determined to uncover the cause of his former partner's death. He thus becomes the white avenger to his black friend's killing.

As part of his investigation, Lyndsey becomes acquainted with Cletus' mixedrace family. Cletus had previously served in the American military and had been stationed in Italy following World War II. There, Cletus had fell in love with Ester Lazarini, an Italian Jew, whom he married and brought back with him to live in New York City. Lyndsey develops a close relationship with the surviving family members, both because he naturally sympathizes with them as survivors of his murdered friend, and because the interracial character of the family reminds him of his own romance with Marvia. A key character in Silver Chariot is Anna Maria, the talented and beautiful ten-year-old daughter of Cletus and Ester. Although still a child, Anna Maria becomes one of Lyndsey's confidants in his investigation. She possesses uniquely attractive physical assets attributed to her mixed-racial background:

Anna Maria looked at Lindsey. He'd never seen eyes like this child's. Huge and liquid. A dark brown shade. The mixture of genes she'd inherited had harmonized to perfection. He thought, if things had worked out differently, if he and Marvia Plum had ever given Jamie a half-brother or-sister, would she be this beautiful and this vibrant? (73)

Within the moral world of Silver Chariot, Anna Maria serves symbolic purposes. As the innocent child survivor of her father's murder, she serves to drive Lyndsey's determination to obtain justice by resolving the crime. She also reminds Lyndsey of his own interracial relationship with Marvia, and her biracial-ness 
vindicates his love for a black woman. Interracialism is thus positioned and presented as the fundamentally good element that the crime has interrupted. Both the white protagonist in the story, and the principal black victim of the murder to be solved, are grounded in interracial love, symbolized by the innocence and beauty of Anna Maria.

The corresponding culprit in Silver Chariot is also a symbolic caricature: Randolph Amoroso - an ambitious white congressman with neo-fascist political viewpoints. Amoroso is an Italian-American who campaigns on pledges of transforming American society into an authoritarian-like society patterned on ancient Rome:

"Well, an honest citizen could walk down the main street of Julius Caesar's Rome and not get mugged, my friends. Nobody tried to sell him a syringe full of poisonous dope. And nobody offered to sell him a magazine full of kiddie porn, either."

He shook his head ruefully.

"The new Roman Empire?" He paused for a beat. Another beat. "The New Roman Empire?" he repeated. "I think it's a great idea." (28)

As Lyndsey gradually unravels the plot, he learns that Cletus had been searching for a mysterious statuette of a silver chariot with origins in biblical times. The silver chariot had previously been owned by Julius Caesar, and had been passed down in time to Benito Mussolini. Regarded in legend to have granted arcane powers in its owners, Lyndsey learns that Amoroso sought the silver chariot as a modern day incarnation of a Caesar or Mussolini-like leader, and in his quest for it, Cletus had been killed.

The investigation becomes embroiled in a race to discover the whereabouts of the missing chariot. Anna Maria becomes Lyndsey's key assistant in his pursuit of the statuette. Not only does she possess a unique beauty, but she is furnished with uncanny skills and knowledge, not unlike Theresa Asakuma from Rising Sun. She is multilingual, and a computer prodigy. On a whim, the ten-year-old is able to hack into secure government computer systems to search for classified records:

"I hacked into the Pentagon," she admitted. "That was so easy, it hardly even counts. They have all these software locks, but anybody who knows anything can open one in a minute."

.... "Do you want to see my dad's service record?"

"Very much so," Lindsey said. (Lupoff 1996, 172-73)

Anna Maria is also an amazingly talented history genius, so much so that she can masquerade as an ivy league college professor of Italian history in internet 
chat rooms. Lupoff is blunt in his deployment of Anna Maria as an interracial, child-savior figure. From Lindsey's perspective, she is a living symbol of a progressive, enlightened, and better future without racial division:

.... She looked up at Lyndsey.

What eyes! Dark Italian eyes. Dark Hebrew eyes. Dark African eyes.

"But I want to learn about my heritage. I have a rich heritage. I'm everything."

She was the future, Lindsey thought. (Lupoff 1996, 141)

Silver Chariot concludes with the discovery of the lost artifact, and Amoroso is revealed for his crimes and arrested. The satisfaction of the case's denouement is aligned both with resolving the original crime, and positioning interracialism's victory over fascism. Certainly, pitting liberalism over fascism as a conflict of good versus evil is not an uncommon plot in crime fiction. But Silver Chariot goes further by placing interracialism in the realm of the extraordinary. Anna Maria is certainly less normal than abnormal-possessing remarkable abilities that no ten-year-old could possibly have. In this sense, she is similar to Rising Sun's Theresa Asakuma, but minus the tragic half.

Gary Hardwick's Color of Justice (2002) takes the most sophisticated approach towards interracialism of all the works examined, and in this sense can be read against the previous novels as a work of exception. Color of Justice is set in modern day Detroit, and is a loose sequel to Hardwick's other crime dramas Supreme Justice (2001) and Double Dead (1998). Unlike Hardwick's other works which featured black protagonists, the hero in Color of Justice is Detective Danny Cavanaugh, an Irish-American homicide investigator with Detroit's Special Crimes Unit who was raised as the only white kid in a black neighborhood. Because of his upbringing in the inner city, Danny has adapted the mannerisms of his black peers, and all his friends are black. He is deeply aware of the antipathy felt towards his own interracial relationship with his African-American girlfriend Vinny. Danny also has a strained relationship with his alcoholic father, and constantly mulls about the premature death of his mother, who died under mysterious circumstances. These tensions drive Danny to regular counseling sessions with a police psychologist, who tries to assist Danny with his many personal issues.

The crimes in Justice are brutal: a series of serial torture-murders occur among Detroit's black upper-class, all of whom have ties to the city's social and political elite. Danny is tasked with finding the killer as soon as possible. As more murders happen, it becomes apparent that the victims are all light-skinned blacks with multiracial backgrounds, and Danny begins to suspect that this somehow motivated the killings. The specters of both colorism and interracialism become interwoven components of Danny's investigation: 
"This all started with slavery, you know," said Marshall. "When we were brought here, voluntarily or not, the races mixed, voluntarily or not. The slave masters treated their bastard kids better than their darker cousins, and the shit has just been carried on down through the years."

Danny thought again about the victims and their faces. "And just what is the problem?" he asked.

"The lighter the skin, the better the person," said Marshall. "That's the stereotype. Reality is more complicated.... Blacks of all colors married, but there was always a section of the race that intermarried and remained very light-skinned. Some even passed for white. My father told me about the parties with the paper bag by the door, and if you were darker than the bag, your ass couldn't come in."

"So if my killer is all fucked up about color, what could have made him that way?" asked Danny.

"Could be a lot of things," said Marshall. "These days, we're all pretty much in denial about the shit." (196)

Justice squarely confronts colorism among black communities as a social and historical pathology. As the killings are linked to colorism, so is the connection made to interracialism as a potentially destructive force. As the investigation into the murders unfold, interracial tensions within Danny's personal life also escalate. First, Renitta, the sister of his girlfriend Vinny, confronts Danny about their interracial relationship, which she openly despises:

"I know you believe you got a black man's heart," Renitta continued. "Hell, sometimes when you talk, I almost forget myself. Vinny may have been fooled by your so-called soulfulness, but not me. I know that deep down inside, you just like all the other white folks. Against us. And now that Vinny's eyes are opened, she'll see that to make it here in Detroit, where blacks have power, she'll have to get away from you." (128)

Even more damning, Danny learns that his mother's accidental death was actually a suicide. He discovers her diary, and finds that she suffered from chronic depression driven by her son's behavior. Her writings condemn Danny and his interracial relationship with Vinny:

.... [H] 's not really like us at all, not the happy son I always imagined I'd have. He's like all those black people he grew up around. He sounds like them, feels like them, and I can't stand it. We used to argue about it, but I gave up. In the end, he loved them more than me. 
Danny lives in sin with a black woman who I cannot bring myself to like. You always think your son will marry a younger version of you. Not in my case. She is a good person, but she is not me. She is black and my heart breaks to say it, Father, but I can never love her. (230-231)

Although Danny's interracial relationship with Vinny serves as the focal point of the turmoil within his personal life, it is clear that it is the racism of others, and not his interracial love for Vinny, that is the issue. In this sense, Justice departs from the other works examined by distinguishing between interracialism itself as an emblem of abnormality, and racial antagonisms that exist towards interracialism. This is a critical difference because Hardwick does not imbue characteristics or meaning into interracialism or multiracial persons per se.

Color of Justice does, however, make important reference to the trope of multiracial exceptionalism in its climax. Danny discovers that the murder victims were also members of a secret society. This clandestine group harbors a secret plan to control the country through a network of mixed-race, social aristocrats. The group's twisted leader-Virginia Stallworth - envisions a movement of multiracial übermen whose superiority derives from their mixed backgrounds:

Their agenda was to create a separate race within the black race in America, a new race of people who were multi-ethnic. She would split off all those of mixed blood and create an elite minority, one that would be fueled with money, power, and a single vision, her vision.

...

In time they would be joined by mixed-race Latinos, Asians, and others would fill the ranks of her group until they were no longer a minority but the one, true voice of America.... From there, she would get funding for her new organization, which she planned to call the MEPOA, or the Multi-Ethnic Persons of America. (268-269)

This dystopic, almost comic vision draws from, but more importantly, condemns, notions of multiracial exception. Stallworth's strategy for domination is clearly presented as an out of control and extreme form of elitism. The killer is finally revealed to be Stallworth's own deranged son, who was motivated to murder the group's members in order to stop their plan. Danny and his police colleagues capture the son before he can complete his plan to murder his own mother. Ending the story on a positive yet predictable note, Danny is celebrated for capturing the murderer, and Danny returns home the hero to make interracial love with his girlfriend Vinny.

Color of Justice thus relies on the notion of multiracial exceptionalism as a driving component to explain the story's crimes, but unlike Rising Sun or The 
Silver Chariot Killer, it does not validate that trope by actually featuring abnormally talented mixed-race individuals. In this sense, Justice can be read against the other examined novels as the only work which does not reduce multiracial persons into one-dimensional representations of either tragedy or exception. Stallworth's maniacal ambitions to create a multiracial future-elite are juxtaposed against Danny's lived struggles with his interracial upbringing and relationship. By not deploying the types of bizarre or fantastical representations of mixed-race individuals as Lupoff or Crichton do, Justice instead acknowledges and focuses on the very real racial divisions and anxieties that exist on more mundane levels.

Yet Justice is an anomaly. The tragic mulatto figure, albeit in a mitigated form, appears frequently in today's crime fiction. Like Theresa Asakuma or the troubled teens in Shadows At The Spring Show, the mixed-race person is frequently depicted as a socially ostracized outcast. In Ronald M. Gauthier's Crescent City Countdown (2007), a biracial attorney lives with the pain of being marginalized by both black and white:

The White community fully renounced him, his fair, beige skin and soft hair the fluffy color of applesauce so close to that of his father, one of them; but tinged and tainted by the darkened blood of his mother, an outsider from another race, peculiar, heterogeneous, natively identifiably, undeniably Black with the coarse hair and brownish and bluish black complexion baked by the sun-stroked heat of Africa. The Black community ridiculed and found embracing him unnerving, most abhorring his Whiteness and its perceived superiority, its abruptness reminding the angry men and their terrorized, vulnerable women that another despicable rapist who hid behind the bigotry and power and privilege of his status and the weakened, enabling laws of the old South ravaged and walked away with impunity. (Gauthier 2007, 289)

In Barbara Neely's Blanche Among the Talented Tenths (1994), the story's hero-Blanche White-is an African-American amateur sleuth visiting a resort town frequented by upper-class, light-skinned, black families. From Blanche's perspective, the resort's inhabitants separate themselves from other guests, and have internalized a destructive, colorist ideology:

Poor child, she thought. She wondered how soon after the first baby was born of the rape of a black woman by a white man did some slaver decide that light-skinned slaves were smarter and better by virtue of white blood? And how long after that had some black people decided to take advantage of that myth. (Neely 1994, 67) 
One of the most tortured of the town's guests is a light-skinned black man involved in the deaths of several other people at the resort. His racial ambiguity also marks him as an outsider from Blanche's perspective: "You know men his complexion, especially those from proper Negro families, ain't usually got enough soul" (Neely 1994, 101).

Numerous works align death or tragedy with interracial persons. Chang-Rae Lee's Native Speaker (1995) is about a Korean-American spy who infiltrates the political campaign of an up-and-coming city councilman. He and his white wife bear a young child who is the object of ridicule by both young white and Korean children alike (Lee 1995, 95-96, 65). The child's premature death continually haunts the couple:

\begin{abstract}
"An accident?" she cried, nearly hollering. She covered her mouth. Her voice was breaking. "How can you say it was an accident? We haven't treated it like one. Not for a second. Look at us. Sweetie, can't you see, when your baby dies it's never an accident. I don't care if a truck hit him or he crawled out a window or he put a live wire in his mouth, it was not an accident. And that's a word you and I have no business using. Sometimes I think it's more like some long-turning karma that finally came back for us. Or that we didn't love each other. We thought our life was good enough. Maybe it's that Mitt wasn't all white or all yellow. I go crazy thinking about it. Don't you? Maybe the world wasn't ready for him." (Lee 1995, 120)
\end{abstract}

In the minds of the parents, part of their sense of guilt is uneasiness about their own coupling and the child they bore.

In David Robbins' Scorched Earth (2002), the newborn daughter of a black man and white woman is born with anencephaly, and dies almost immediately afterwards (Robbins 2002, 17-21). The remainder of the story is driven by racial tensions sparked by the subsequent burial of the child in a traditionally white cemetery in rural Virginia. A similar storyline exists in Go Close Against the Enemy (1998), in which a pair of amateur detectives help an interracial couple who bury their stillborn son in a traditionally white church cemetery:

Next to her, with his arm over her shoulder, stood her husband, Davon. So they had married after all. And had a child. And the child was born dead. How much more tragic could life get?

I met April only once, during my brief stay in jail. She was there purely to be harassed for having a black boyfriend, a ploy instigated, she said, by her own father, in the hope that it would scare her into giving up Davon. (Iakavou and Iakavou 1998, 7) 
In Michael Connelly's The Closers (2005), the teenage victim of an unsolved murder is also the daughter of a black father and white mother (Connelly 2005). The violent murder of a young half-Vietnamese, half-white woman in a New York City alley opens Michael Collins' Minnesota Strip (Collins 1987, 3). It is later revealed that the victim also worked in a brothel, and was used by smugglers to traffic illicit items from Asia to the United States (Collins 1987, 85).

In a nod towards Absalom, Absalom!, Whitney Terrell's The Huntsman (2001) positions miscegenation in the same moral universe as an incestuous relationship within a prominent family (Terrell 2001). The plot centers around the white daughter of a well-known Kansas City judge, who uses her romantic relationship with a young black man to seek revenge against her father, with whom she also has had a consensual sexual relationship. At first, the daughter flaunts her interracial affair to embarrass her father by taking her lover out among Kansas City's conservative, white elite, social scene:

She developed an odd obsession with seeing her father - or, more important, it seemed to Booker (though she denied it), with her father seeing them. Late in the tawdry, final hours of a party, when it had become clear that her father wouldn't show, she would grow aggressively, almost embarrassingly amorous and (particularly on nights when she had had too much to drink) would make sexual proposals that Booker hadn't heard of even in jail. (Terrell 2001, 173)

The daughter later attempts to punish her father through an attempt at blackmail, and enlists her black lover as an accomplice. Ultimately, the father brutally slays his own daughter in a fit of rage, provoked by her rejection of him for a young black man:

"The fact that what really upsets you, Mr. Federal judge, friend to all minorities, is that your daughter is sleeping with a black."

The judge broke stride so abruptly that Clarissa nearly ran in to him....

"You have always," Clarissa said, enunciating slowly, "disgusted me. Fucking you is like fucking something rotten, a dirty, sick old man."

The judge stroked his putt. He hit it too hard, though right on the line, the ball shooting straight across the cup without stopping, and he whirled, as if on a follow-through, and swung the putter like a baseball bat, the toe of it punching through the soft bone of his daughter's temple, just above her ear. (Terrell 2001, 287-288) 
In the moral world of The Huntsman, the act of miscegenation in itself is a form of rebellion and vengeance. Because the daughter's interracial relationship is born out of her hatred for her father and his sexual perversions, it is depicted as the end result of their tragic and sinful behavior.

Portrayals of mixed-race people as superior or exceptional in comparison with monoracial individuals are also not uncommon in contemporary crime fiction. Besides Lupoff's character, Anna Maria, several novels depict multiracial persons as symbols of social progress, or gifted individuals with rare talents and physical beauty. Typically, the language employed in such representations allude to mixed-race persons as living embodiments of multiracial harmony or unity. In Lawrence Block's Hope To Die, the main protagonist's granddaughter is a half-white, half-Chinese girl:

Michael and June have a daughter, Melanie, and a year ago Elaine and I flew out for a long weekend in San Francisco, in the course of which we drove to San Jose for a look at my granddaughter. June is third-generation Chinese-American, slim and exquisite, and Melanie is one of the more powerful arguments for interracial marriage. (Block 2002, 29)

In Grif Stockley's Illegal Motion (1995), the white protagonist mulls over the beauty of his own mixed-race daughter who has entered cheerleader tryouts at her school:

They would be crazy not to make her a cheerleader. Part Hispanic, Indian, and black as a result of her Colombian mother's ancestry, Sarah would not only help solve some cultural diversity problems but she is also a knockout. Voted a campus beauty her freshman year, she is the picture of her mother, who, even at the end of an eight-hour shift at St. Thomas Hospital, where she worked as a nurse, could look stunningly lovely. (Stockley 1995, 8)

In this narrative, miscegenation not only produces exceptional beings, but can also contribute to a post-racial society free of the divisions or pathologies that bedevil a race-conscious nation. The "hump for a better world" fictive, or fetish, depending on one's view, is alluded to in Don Lee's Country of Origin (2004): "For a while on the Berkeley campus, some biracial student activists had campaigned for miscegenation as the country's only hope and, with great merriment, had handed out leaflets that crooned 'Cross-Fuck for a Better World!'” (Lee 2004, 67).

Portrayals of physically appealing, mixed-race individuals abound in modern crime works. In Barbara Neely's Blanche Among the Talented Tenths, one of the story's main characters is a very light-skinned, black male who serves as both a suitor to the protagonist, as well as a suspect in a series of deaths: 
His skin was milk with a dollop of coffee, instead of the other way around. He was muscular without being gross with long, elegant hands and blue-green eyes. His medium brown hair had just a hint of a wave. There was a dusting of gray, like the first snowflakes, at his temples. Damn! Blanche though, he probably gets anonymous pussy in the mail. (Neely 1994, 34)

In Brandon Massey's horror-thriller Within the Shadows (2007), the story's protagonist finds himself drawn into a series of mysterious and supernatural events sparked by a romantic relationship with a beautiful, multiracial woman who-at least at the outset—seems to be near perfect:

This close, she was even more breathtaking. Dark hair flowed
to her slim shoulders in luxuriant waves. Her smooth, reddish-
brown skin shone with a healthy glow.
$\ldots$ He guessed that she was biracial. Probably had African
American and Caucasian blended in her genes. He wasn't
one of those brothers who dated only light-skinned women.
He dated sisters from all ranges of the color spectrum. To him,
beauty was beauty. And this woman possessed it, in abundance.
(Massey 2007, 47)

The former girlfriend of a Portland cop in James F. David's Before The Cradle Falls (2004) is a part-time fashion model: "Cassidy was a beautiful woman. She was a multiracial mix of African, Asian, and Caucasian, with dark oval eyes, almond-colored skin, and a slender figure" (David 2004, 49). In J.D. Robb's Interlude In Death (2006), the wife of the police commander is described as a "striking woman .... either superior DNA or an excellent face-and-body team had kept her beauty youthful. Her hair was richly black, and the gorgeous tone of her skin indicated mixed race" (Robb 2006, 11). Michael Connelly's The Closers (2005) also features a beautiful young mixed girl in the investigation of a murder: "Robert Verloren was black and Muriel Verloren was white. Bosch now understood where their daughter had gotten her growing beauty. The mix of races in a child often rose above the attendant social difficulties to achieve such grace" (Connelly 2005, 54).

\section{Conclusion: Tragedy or Perfection?}

There are many examples of works that depart from the themes discussed in this article. For example, Kyra Davis' Sophie Katz and Walter Mosely's Leonid McGill series both offer refreshingly different presentations of interracialism, not so much through affirmative narration, but by what they do not do. Instead of reducing multiracial figures to the dualities of either misfortune or exception- 
alism, these series subtly acknowledge society's obsession with racial identity and compartmentalization without ascribing meaning to interracialism per se. Yet this minority of works stands against the patterns discussed in this article. The depiction of interracialism in contemporary American crime fiction both reflects and exploits our anxieties about race and race relations. The continuing presence of the tragic mulatto in modern works of fiction is clearly problematic, yet not surprising given its long historical legacy. The portrayals of mixed race persons as tragic, social outcasts in crime fiction may reflect these continuing reservations. This heavy handed portrayal of multiracial characters as angry, lonely, embittered persons is strikingly reductionist in nature. One wonders if the tragic mulatto archetype has any grounds in reality beyond the fields of literature, popular culture, and the stereotype of the non-white struggle to "act white" (Spencer 2006, 43). ${ }^{6}$ Although liminality or marginalization may be a part of the multiracial experience, overemphasizing one thread of experience and expanding it to subsume the entire essence of a person's character is certainly dehumanizing.

The frequent appearance of the mixed-race super person is more worrisome. On one level, this trend can be explained by the larger fad of multiracialism or racial ambiguity that exists in popular culture generally. With the increasing number of popular actors, athletes, musicians, and other celebrities claiming mixed-racial heritage, multiracialism has become a rather en vogue phenomena that swept through a number of American pop culture mediums with a vengeance in the 2000s (Spickard 2001, 76). Although unquestionably a larger social phenomena exists of increasing rates of both interracial marriages and people claiming multiracial identities, in pop culture the line blurs when it comes to recognizing when representations of interracialism are deemed to be "appropriate" by whatever subjective or contextual lens one chooses to employ, versus portrayals that are more trivial or dehumanizing in nature. My point though is not to demarcate the line of "appropriateness" between portrayals of interracialism in popular television dramas such as Lost, versus the music videos of Alicia Keys. Such an analysis would in itself fail by virtue of its attempt to simplify such a large scope of content without the contextual analysis individual texts would demand. Indeed, race would not be the conundrum of our times if it were not for the fact that it is the most contextual and multi-layered discourse or discourses in modern America.

On one level, the mixed-race super person may be construed as challenging conservative attitudes towards miscegenation by endowing multi-racial characters with an abundance of positive characteristics. As the number of interracial relationships, globalization, and migration, all increase, positive portrayals of multiracial and/or multicultural people do serve to mitigate historically racist notions that miscegenation is bad or immoral, and that the multiracial person is in whatever way inferior to the monoracial one. Additionally, the presence of multiracial persons within the ongoing race discourse confronts the long-standing, traditional binaries of black vs. white, white vs. non-white, and privileged vs. 
marginalized; and offers the potential for a much greater and deeper understanding of diversity (Trepanier 2000). ${ }^{7}$

However, supplanting negative group stereotypes with positive ones pose more difficulties - whether it is mental acuity, physical excellence, or other admirable characteristics or behavior. By lauding the multiracial other as an exceptional being - particularly when the work in question features a white protagonist in the position of narrator - the monoracial person of color as other is simultaneously circumscribed as having the least value. What this results in, ironically, is an affirmation of a racial caste-like hierarchy in which the white protagonist as narrator is the central, dominant being, followed by the mixedrace person - who is often partially white - and finally, the other non-white races inhabit the bottom of the hierarchy (Bonilla-Silva and Embrick 2006, 33-34). ${ }^{8}$ This structuring comports with the cynical criticism that some persons of mixed white/non-white heritage distance themselves - perhaps unconsciously - from their non-white background (an accusation often rejected by many multiracial persons, and understandably so).

For instance, what agendas drive the myth of the exceptional multiracial person? Multiracial exceptionalism might be an expression of a desire to portray multiracial persons as being better than non-white, monoracial persons. The "ordinary" black, brown, or yellow person may dwell in the realm of marginal and inferior otherness, yet if mixed with white genes and features, they are celebrated as magisterial beings possessing exceptional mental and physical traits. In the mythological worlds of crime fiction, such multiracial super-beings make for good characters.

But I would argue that a more likely agenda behind such reductive and trivial representations is a desire to apologize for the historical legacy of racism and racial separation by endowing multiracial characters with social advantage. The multiracial super-child in Lupoff's The Silver Chariot Killer is one prominent example. Of course, such depictions do serve to counter traditional resentment of interracial couplings and multiracial persons. But such representations are clumsy at best, and beg the question of whether or not such bizarre attempts at apology for racism are truly productive. From a standpoint of honest, racial reconciliation and discourse, such departures are diversionary if not disingenuous. Imagining multiracial peoples as symbols of social harmony that can vault us into a "post-racial" era frees us from the anxiety-generating experience of actually confronting and discussing race and racism. It is the easiest of easy outs from the bewildering maze of race in contemporary American society. These issues do, however, form an inquiry perhaps too grim for popular fiction (Raimon 2004, 147-154). ${ }^{9}$ For now, in the streets of American crime fiction, interracialism stands at the cross roads of tragedy, or perfection. 


\section{Notes}

I would like to thank Seanna Oakley and Greg Rutledge for the many opportunities to discuss and process this topic, their thoughtful advice, and criticism.

1. Doyle, Arthur. "The Sign of the Four," in The Complete Sherlock Holmes 89, 127 (1930); and "The Red-Headed League," in The Complete Sherlock Holmes 176, 177 (1930).

2. See Suzanne Bost, Mulattas and Mestizas: Representing Mixed Identities in The Americas, 1850-2000, (Athens, GA: University of Georgia Press, 2003), 60-68. Bost discusses the works of Elizabeth Livermore and Dion Boucicault, and notes that "[t]o maximize reader sympathy, any possible resistance or transcendence was dismissed in favor of ultimate suicide or violation"); Penelope Bullock, in "The Mulatto in American Fiction," Phylon 6 (1945): 78, discusses the works of Richard Hildreth, Harriet Beecher Stowe, William Wells Brown and others, and asserts that "[f]rom their novels emerges in bold, simple outline a major, stereotyped figure").

3. See Donald M. Kartiganer, "Faulkner's Absalom, Absalom!: The Discovery of Values," American Literature 37 (1965): 303. Kartiganer asserts that "Charles Bon becomes a primary threat to that world because he seeks a different kind of relation among men, a true communion, in which father and son may meet as individuals." Dayton Kohler, in "William Faulkner and the Social Conscience," College English 11 (1949): 124-25, asserts among Faulkner's works the focus that "slavery was the curse of the old order and that the Negro, along with the white man, is the victim of a system which created unequal and often heartless relationships between the races." Karl F. Zender, in "Faulkner and the Politics of Incest," American Literature 70 (1998): 752, notes that "hysteria over miscegenation dominates Southern racial attitudes."

4. For an early, classic examination of the tragic mulatta in fiction, see Sterling A. Brown, "Negro Character as Seen by White Authors," Journal of Negro Education 2 (1933): 192-196. Despite his reputation for being anti-slavery, Twain has been criticized for his depictions of black slaves as comic tropes, albeit a common literary practice for his age. See Robert Rowlette, Twain's Pudd'nhead Wilson: The Development and Design (Bowling Green, OH: University of Ohio Popular Press, 1971) 5-7, 11-13, for a discussion noting Twain's use of and departure from stereotypical depictions of black slaves in his works; and Lawrence Howe, "Race, Genealogy, and Genre in Mark Twain's Pudd'nhead Wilson," Nineteenth Century Literature 46 (1992): 495-97, hypothesizing that the story's plot turns on stereotypical fears towards blacks who can pass for whites.

5. The controversies are quite well-known. On an existential level, critics have alleged that transracial adoption can amount to a form of cultural displacement and substitution which, depending on the context, can amount to a form of cultural destruction by removing children from their original environments and cultures. On a more practical level, and as referenced continually by Waits in her portrayals of adoptees, is the concern that transracial adoptees will experience poor self-esteem or social isolation because of an inability to adapt to a different environment, or racist attitudes. See Femmie Juffer and Marinus H. van IJzendoorn, "Adoptees Do Not Lack Self-Esteem: A Meta-Analysis of Studies on Self-Esteem of Transracial, International, and Domestic Adoptees," Psychological Bulletin 133 (2007): 1077-1079, in which the authors describe results from a metaanalysis of studies conducted about self-esteem and cultural issues among transracially adopted children; and Arnold R. Silverman, "Outcomes of Transracial Adoption," The Future of Children 3 (1993): 114-118, discussing concerns about self-image and cultural identies of transracially adopted children and their mental and emotional health outcomes. 2006), 43:

6. See Rainier Spencer, Challenging Multiracial Identity (Boulder, CO: L. Rienner Publishers,

[T]here has first of all never been any actual, reliable, nonclinical evidence demonstrating that black/white persons have truly been tragically conflicted and mentally ill through the centuries. The tragic mulatto myth has grown as a result of folklore, as a result of psychological projection by whites who find comfort in the idea of black/white individuals striving to be white, as a result of maudlin literature.

7. For an excellent discussion on how multiracialism can challenge static notions of race and identity, see Tania Trepanier, "How Hybridity Can Move Us Beyond the Stalemate of Identity Politics," in Visions of the 21 $1^{\text {st }}$ Century: Social Research for the Millennium, ed. Martin Schoenals and Joseph E. Behaor (Binghamton, NY: Global Academic Publishing), 205-14.

8. See Eduardo Bonilla-Silva and David G. Embrick, "Black, Honorary White, White: The Future of Race in the United States," in Mixed Messages: Multiracial Identities in the 'Color-Blind' Era," ed. David L. Brunsma (Boulder, CO: Lynne Rienner Publishers, 2006), 33-34. The authors assert a future racial hierarchy in which whites inhabit the top position, blacks the bottom, and most multiracial people in between.

9. See Eve Allegra Raimon, The "Tragic Mulatta" Revisited: Race and Nationalism in Nineteenth-Century Antislavery Fiction (Piscataway, NJ: Rutgers University Press, 2004), 147-54, for a discussion of the reluctance with which modern popular culture has failed to properly address issues of interracialism within the context of slavery, citing examples of current treatment of the Thomas Jefferson/Sally Hemings story. 


\section{References}

Block, Lawrence. 2002. Hope To Die. New York: HarperTorch.

Bonilla-Silva, Eduardo and David G. Embrick. 2006. "Black, Honorary White, White: The Future of Race in the United States." In Mixed Messages: Multiracial Identities in the 'Color-Blind' Era," ed. David L. Brunsma, 33-48. Boulder, CO: Lynne Rienner Publishers.

Bost, Suzanne. 2003. Mulattas and Mestizas: Representing Mixed Identities in The Americas, 1850-2000. Athens, GA: University of Georgia Press.

Brown, Sterling. 1933. "Negro Character as Seen by White Authors." Journal of Negro Education 2: 55-89.

Bullock, Penelope. 1945. "The Mulatto in American Fiction.” Phylon 6: 78-82. Cawelti, J. 1997. "Canonization, Modern Literature, and the Detective Story." In Theory and Practice of Classic Detective Fiction, eds. Jerome H. Delamater and Ruth Prigozy, 6-8. Westport, CT: Greenwood Press.

Child, Lydia Maria. 1842. "The Quadroons." In The Liberty Bell for 1842. Available online at The Online Archive of Nineteenth-Century U.S. Women's Writings, http://www.facstaff.bucknell.edu/gcarr/19cUSWW/LB/.

Collins, Michael. 1987. Minnesota Strip. Dallas, TX: Texas Bookman Remainders.

Connelly, Michael. 2005. The Closers. New York: Grand Central Publishing.

Crichton, Michael. 1969. The Andromeda Strain. New York: Harper. . 1972. The Terminal Man. New York: Harper. 1975. The Great Train Robbery. New York: Harper. . 1976. Eaters of the Dead. New York: Harper. 1980. Congo. New York: Harper. 1987. Sphere. New York: Ballantine Books. . 1990. Jurassic Park. New York: Ballantine Books. 1992. Rising Sun. New York: Alfred A. Knopf. 1994. Disclosure. New York: Ballantine Books.

David, James F. 2004. Before The Cradle Falls. New York: Forge Books. Faulkner, William. 1936. Absalom, Absalom! New York: Random House.

Gauthier, Ronald M. 2007. Crescent City Countdown. New Orleans, LA: JoJo Press.

Hardwick, Gary. 2002. Color of Justice. New York: HarperTorch.

Howe, Lawrence. 1992. "Race, Genealogy, and Genre in Mark Twain's Pudd'nhead Wilson," Nineteenth Century Literature 46: 495-516.

Iakavou, Takis, and Judy Iakavou. 1998. Go Close Against the Enemy. Toronto: Worldwide Library Mysteries.

Jehlen, Myra. 1990. "The Ties That Bind: Race and Sex in Pudd'nhead Wilson." American Literary History 2: 39-55.

Juffer, Femmie and Marinus H. van IJzendoorn. 2007. Adoptees Do Not Lack Self-Esteem: A Meta-Analysis of Studies on Self-Esteem of Transracial, International, and Domestic Adoptees. Psychological Bulletin 133: 1067-1083. 
Kenschaft, Lori. 2002. Lydia Maria Child: The Quest for Racial Justice. New York: Oxford University Press.

Kartiganer, Donald. 1965. "Faulkner's Absalom, Absalom!: The Discovery of Values." American Literature 37: 291-306.

Kohler, Dayton. 1949. William Faulkner and the Social Conscience. College English 11: 119-127.

Lee, Chang-Rae. 1995. Native Speaker. New York: Riverhead Trade.

Lehmann-Haupt, Christopher. 1992. "Books of The Times; Investigating a Murder Japan Wants Unsolved." New York Times, January 30.

Libretti, Tim. 1999. "Lucha Corpi and the Politics of Detective Fiction." In Multicultural Detective Fiction: Murder from the Other Side, ed. Adrienne Johnson Gosselin, 61-81. New York: Garland Publishing, Inc.

Lupoff, Richard. 1996. The Silver Chariot Killer. New York: St. Martin's Press. Malmgren, Carl. 2001. Anatomy of Murder. Madison, WI: Popular Press.

Marcus, George. 1990. "'What did he reckon would become of the other half if he killed his half?': Doubled, Divided, and Crossed Selves in Pudd'nhead Wilson; or Mark Twain as Cultural Critic in His Own Times and Ours." In Mark Twain's Pudd'nhead Wilson: Race, Conflict, and Culture, ed. Susan Gillman and Forest G. Robinson, 190-210. Durham, NC: Duke University Press.

Massey, Brandon. 2007. Within the Shadows. New York: Dafina.

Neely, Barbara. 1994. Blanche Among the Talented Tenths. New York: St. Martin's Press.

Olumide, Jill. 2002. Raiding the Gene Pool: The Social Construction of Mixed Race. London: Pluto Press.

Raimon, Eve Allegra. 2004. The "Tragic Mulatta” Revisited: Race and Nationalism in Nineteenth-Century Antislavery Fiction. Piscataway, NJ: Rutgers University Press.

Robb, J.D. 2006. Interlude In Death. New York: Berkley.

Robbins, David. 2002. Scorched Earth. New York: Bantam.

Rowlette, Robert. 1971. Twain's Pudd'nhead Wilson: The Development and Design. Bowling Green, OH: Bowling Green University Popular Press.

Silverman, Arnold. 1993. Outcomes of Transracial Adoption. The Future of Children 3: 104-118.

Sollors, Werner. 1997. Neither Black Nor White Yet Both. New York: Oxford University Press.

Spencer, Rainier. 2006. Challenging Multiracial Identity. Boulder, CO: L. Rienner Publishers.

Spickard, Paul. 2001. "The Subject is Mixed Race: The Boom in Biracial Biography." In Rethinking 'Mixed Race', ed. David Parker and Miri Song, 76-98. London: Pluto Press.

Stockley, Grif. 1995. Illegal Motion. New York: Fawcett.

Terrell, Whitney. 2001. The Huntsman. New York: Penguin. 
Trepanier, Tania. 2000. "How Hybridity Can Move Us Beyond the Stalemate of Identity Politics." In Visions of the $21^{\text {st }}$ Century: Social Research for the Millennium, ed. Martin Schoenals and Joseph E. Behaor, 193-226. Binghamton, NY: Global Academic Publishing.

Twain, Mark. 1955. Pudd'nhead Wilson. New York: Norton.

Wait, Lea. 2005. Shadows At The Spring Show. New York: Simon \& Schuster.

Zanger, Jules. 1966. "The ‘Tragic Octoroon' In Pre-Civil War Fiction.” American Quarterly 18: 63-70.

Zender, Karl. 1998. "Faulkner and the Politics of Incest." American Literature 70: 739-765. 
